Article

\title{
Methanol Extract from Anogeissus leiocarpus (DC) Guill. et Perr. (Combretaceae) Stem Bark Quenches the Quorum Sensing of Pseudomonas aeruginosa PAO1
}

\author{
Vincent Ouedraogo and Martin Kiendrebeogo * \\ Laboratoire de Biochimie \& Chimie Appliquées, Université Ouaga 1 Pr. Joseph KI-ZERBO, \\ Ouagadougou, 03 BP 7021, Burkina Faso; vicenteoued@gmail.com \\ * Correspondence: martinkiendrebeogo@yahoo.co.uk; Tel.: +226-70-608-590 \\ Academic Editor: James D. Adams \\ Received: 27 August 2016; Accepted: 29 September 2016; Published: 6 October 2016
}

\begin{abstract}
Background: Due to its extensive arsenal of virulence factors and inherent resistance to antibiotics, Pseudomonas aeruginosa is a threat particularly in immunocompromised patients. Considering the central role of quorum sensing in the production of virulence factors, inhibition of bacterial communication mechanism constitute an opportunity to attenuate pathogenicity of bacteria resistant to available antibiotics. Our study aimed to assess the anti-quorum sensing activity of Anogeissus leiocarpus, traditionally used in Burkina Faso, for the treatment of infected burn wounds. Methods: Investigations were carried out on methanol extract from A. leiocarpus stem bark. The reporter strains Chromobacterium violaceum CV026 and P. aeruginosa PAO1 derivatives were used to evidence any interference with the bacterial quorum sensing and expression of related genes. P. aeruginosa PAO1 was used to measure the impact on pyocyanin production. Results: At a sub-inhibitory concentration $(100 \mu \mathrm{g} / \mathrm{mL})$, A. leiocarpus methanol extract quenched the quorum sensing mechanism of $P$. aeruginosa PAO1 by down-streaming the $r h l R$ gene, with a subsequent reduction of pyocyanin production. Moreover, the antioxidant polyphenols evidenced are able to reduce the oxidative stress induced by pyocyanin. Conclusion: The antioxidant and anti-quorum sensing activities of $A$. leiocarpus stem bark could justify its traditional use in the treatment of infected burn wounds.
\end{abstract}

Keywords: Anogeissus leiocarpus; Chromobacterium violaceum CV026; Pseudomonas aeruginosa PAO1; pyocyanin; quorum sensing

\section{Introduction}

Pseudomonas aeruginosa infections are common following burn injuries [1] and often present as wound infections [2]. Due to its extensive arsenal of virulence factors and inherent resistance to several antibiotics, approximately $80 \%$ of burn patients infected with P. aeruginosa die of septicaemia [3]. Production of virulence factors by P. aeruginosa is under the control of a cell-to-cell communication system termed quorum sensing (QS), which is a mechanism used by many bacteria to detect their critical cell numbers through the release and perception of small diffusible signal molecules called auto inducers, in order to coordinate a common behavior [4-6].

In $P$. aeruginosa, two QS systems (lasI/lasR and rhlI/RhlR) drive the production (by the synthetases LasI and RhlI) and the perception (by the transcription factors LasR and RhlR) of the auto inducers acyl homoserine lactones (AHL) $-N$-(3-oxododecanoyl)-L-homoserine lactone (3-oxo-C12-HSL) and N-butanoyl-L-homoserine lactone (C4-HSL), respectively [4,5,7,8]. A third 
QS system, based on quinolone signals, links and interacts in an intricate way with the lasI/lasR and rhlI/RhlR quorum-sensing systems [9-12].

Following injuries, inflammation process (representing a non-specific immune response to chemical or biological aggression) takes place in order to pathogen elimination and tissue injury reparation [13-15].

Inflammatory reactions start with the release of inflammatory mediators (e.g., cytokines, endotoxins, prostaglandins, leukotrienes, and histamine) as well as reactive oxygen species (ROS) by injured cells.

In non-pathogenic conditions, cells are normally able to defend themselves against ROS damage through the use of endogen enzymatic and non-enzymatic antioxidants agents. Since P. aeruginosa infection during a burn wound dramatically boosts the level of ROS, antioxidant defense systems of cells are overpassed, resulting in oxidative stress with significant damage to cell structures [16,17].

In the ongoing struggle against bacterial infection, antibiotics are commonly used to kill pathogenic bacteria. However, bacteria increasingly exhibit resistance against available antimicrobial drugs $[18,19]$. To cope with these limitations, the alternative approach consisting in attenuating the expression of bacterial virulence factor without affecting their viability by using anti-QS agents has become a rational preventive strategy $[20,21]$.

In Burkina Faso, more than $80 \%$ of the population relies on traditional practices and medicinal plants to treat various diseases [22]. Some medicinal plants have been reported to present anti-inflammatory activity and wound healing effects without any antibacterial activity [22,23], which suggests a non-antimicrobial modulation of virulence factors.

In this study, Anogeissus leiocarpus (DC) Guill. \& Perr. (Combretaceae), which is traditionally involved in Burkina Faso for the treatment of infected burn wounds [22], was investigated for its ability to reduce the production of pyocyanin, one of the QS-controlled virulence factors produced by P. aeruginosa, and to interfere with the bacterial QS system. Total polyphenol and flavonoid content as well as the antioxidant potentiality of this medicinal plant were also assessed.

\section{Materials and Methods}

\subsection{Bacterial Strains, Plasmids, and Culture Conditions}

Chromobacterium violaceum CV026, Pseudomonas aeruginosa PAO1, and its derivatives (Table S1) harboring plasmids pPCS1001 ( $\mathrm{P}_{\text {lasR }}$-lacZ transcriptional fusion), $\mathrm{p} \beta 03$ ( $\mathrm{P}_{\text {las }}$-lacZ transcriptional fusion), pPCS1002 ( $\mathrm{P}_{\text {rhlR }}$-lacZ transcriptional fusion), pLPR1 ( $\mathrm{P}_{\text {rhlI }}$-lac $Z$ transcriptional fusion), pTB4124 ( $\mathrm{P}_{a c A e}$-lac $\mathrm{Z}$ transcriptional fusion) and $\mathrm{p} \beta 02$ ( $\mathrm{P}_{\text {rhl }}$-lac $\mathrm{Z}$ transcriptional fusion) were provided from the Laboratoire de Biotechnologie Vegetale (Université Libre de Bruxelles, Gosselies, Belgium). P. aeruginosa PAO1 $\left(37^{\circ} \mathrm{C}\right.$, agitation $\left.175 \mathrm{rpm}\right)$ and C. violaceum $\mathrm{CV} 026\left(30^{\circ} \mathrm{C}\right.$, agitation $\left.175 \mathrm{rpm}\right)$ were grown in LB broth. P. aeruginosa PAO1 derivatives strains were grown $\left(37^{\circ} \mathrm{C}\right.$, agitation $\left.175 \mathrm{rpm}\right)$ in LB-MOPS broth (50 mM, pH 7) supplemented with carbenicillin $(300 \mu \mathrm{g} / \mathrm{mL})$.

\subsection{Plant Material Collection and Extraction}

Stem bark of Anogeissus leiocarpus (DC) Guill. et Perr. (Combretaceae) was collected in August 2014 at Gampela ( $25 \mathrm{~km}$, east of Ouagadougou, Burkina Faso). Botanical identity was assessed by Dr. Amade Ouedraogo from the Laboratoire de Biologie et Ecologie Vegetale (Université Ouaga 1 Pr. Joseph Ki-Zerbo, Ouagadougou, Burkina Faso) where a voucher specimen (ID: 16883) was deposited. Plant material was dried at room temperature, ground into fine powder, and stored in an airtight bag until use.

Powdered plant material $(100 \mathrm{~g})$ was defatted with petroleum ether $(500 \mathrm{~mL})$ in a soxhlet extractor (Wheaton industries Inc., Millvile, NJ, USA) and soaked $\left(24 \mathrm{~h}, 25^{\circ} \mathrm{C}\right.$, continuous stirring) in methanol. Extract was filtrated, concentrated in a vacuum evaporator (Büchi Labortechnik AG, Postfach, Flawil, Switzerland) and dried to obtain $14.4 \mathrm{~g}$ of plant extract. Plant extract $(100 \mathrm{mg} / \mathrm{mL})$ was dissolve 
either in methanol for phytochemical purpose or in dimethyl sulfoxide (DMSO) for testing on bacterial strains. Test samples were stored at $4{ }^{\circ} \mathrm{C}$ until use.

\subsection{Total Polyphenol and Flavonoid Content Determination}

Total polyphenol was determined according to the colorimetric method of Folin-Ciocalteu [24]. Plant extract $(25 \mu \mathrm{L}, 100 \mu \mathrm{g} / \mathrm{mL}$ in methanol) was mixed with Folin-Ciocalteu Reagent (125 $\mu \mathrm{L}, 0.2 \mathrm{~N})$ and, $5 \mathrm{~min}$ later, with sodium bicarbonate $(100 \mu \mathrm{L}, 75 \mathrm{~g} / \mathrm{L})$. After incubation $(1 \mathrm{~h}$, room temperature), absorbance was measured at $760 \mathrm{~nm}$ against a methanol blank. Gallic acid $(0-100 \mathrm{mg} / \mathrm{L})$ was used to generate a standard calibration curve $\left(Y=0.005 X+0.00968 ; R^{2}=0.99\right)$, and total polyphenol content was expressed as mg gallic acid equivalent to $100 \mathrm{mg}$ of plant extract (mg GAE/100 mg).

Total flavonoid was estimated according to the Dowd method [24]. Plant extract $(75 \mu \mathrm{L}$, $100 \mu \mathrm{g} / \mathrm{mL}$ in methanol) was mixed with aluminium trichloride $(75 \mu \mathrm{L}, 2 \%$ in methanol). Absorbance was subsequently read at $415 \mathrm{~nm}$ after incubation (10 $\mathrm{min}$, room temperature) against a methanol blank. Quercetin $(0-100 \mathrm{mg} / \mathrm{L})$ was used to plot a standard calibration curve $(Y=0.02891 X+0.0036$; $R^{2}=0.99$ ), and total flavonoid content was expressed as $\mathrm{mg}$ of quercetin equivalent to $100 \mathrm{mg}$ of plant extract (mg QE/100 mg).

\subsection{Antioxidant Assays}

Antioxidant activity was measured through 2,2-diphenyl-1-picrylhydrazyl (DPPH) and ferric reducing antioxidant power (FRAP) assays as previously described [24].

For the DPPH assay, freshly prepared DPPH solution $(200 \mu \mathrm{L}, 0.02 \mathrm{mg} / \mathrm{mL}$ in methanol) was mixed with plant extract ( $100 \mu \mathrm{L}, 100$ to $0.39 \mu \mathrm{g} / \mathrm{mL}$ in methanol). The mixture was subsequently shacked and incubated (15 min in darkness, room temperature), and absorbance was measured at $517 \mathrm{~nm}$ against a methanol blank. DPPH radical scavenging activities were plotted against sample concentrations, and the result was expressed as a sample concentration scavenging $50 \%$ of DPPH radicals (IC50). Quercetin was used as positive controls.

For FRAP testing, plant extract $(100 \mu \mathrm{L}, 100 \mu \mathrm{g} / \mathrm{mL}$ in methanol) was mixed with a phosphate buffer $(250 \mu \mathrm{L}, 0.2 \mathrm{M}, \mathrm{pH} 6.6)$ and a potassium hexacyanoferrate solution $(250 \mu \mathrm{L}, 1 \%$ in water). After incubation $\left(30 \mathrm{~min}, 50{ }^{\circ} \mathrm{C}\right)$, trichloroacetic acid $(250,10 \%$ in water) was added, and the mixture centrifuged $(2000 \times g$ for $10 \mathrm{~min})$. The supernatant $(125 \mu \mathrm{L})$ was mixed with water $(125 \mu \mathrm{L})$ and a fresh $\mathrm{FeCl}_{3}$ solution ( $25 \mu \mathrm{L}, 0.1 \%$ in water) to read absorbance at $700 \mathrm{~nm}$. Ascorbic acid was used to plot a calibration curve $\left(R^{2}=0.99\right)$. Reducing power was expressed as $\mu \mathrm{M}$ ascorbic acid equivalent per gram of plant extract ( $\mu \mathrm{M} \mathrm{AAE} / \mathrm{g})$. Quercetin was used as positive controls.

\subsection{Determination of $M I C$ and $M B C$}

MIC (minimum inhibitory concentration) values on P. aeruginosa PAO1 and C. violaceum CV026 were determined according to the micro dilution method, using $p$-iodonitrotetrazolium (INT) as an indicator of bacterial growth [25]. In brief, an overnight bacterial culture was diluted with LB broth to obtain a starting inoculum $(109 \mathrm{CFU} / \mathrm{mL})$. Inoculum $(180 \mu \mathrm{L})$ was added to serial dilutions of test extract $(20 \mu \mathrm{L} ; 50$ to $0.39 \mathrm{mg} / \mathrm{mL}$ in DMSO $10 \%$ ) to obtain a final concentration range of $5 \mathrm{mg} / \mathrm{mL}$ to $0.039 \mathrm{mg} / \mathrm{mL}$. Mixtures were incubated for $18 \mathrm{~h}\left(37^{\circ} \mathrm{C}, 175 \mathrm{rpm}\right.$ agitation). After $18 \mathrm{~h}$ of incubation, $50 \mu \mathrm{L}$ of INT $(0.2 \mathrm{mg} / \mathrm{mL})$ was added to each well, and the microplate was further incubated $\left(37^{\circ} \mathrm{C}\right.$, $30 \mathrm{~min}$ ). Bacterial growth was indicated by a red color within the microplate wells (Greiner Bio-One $\mathrm{GmbH}$, Frieckenhausen, Germany).

To determine the $\mathrm{MBC}$, aliquots of $20 \mu \mathrm{L}$ from all dilutions not showing any bacterial growth were spread onto $\mathrm{LB}$ agar plates and incubated $\left(37^{\circ} \mathrm{C}, 24 \mathrm{~h}\right)$. The minimum concentration for which there is no visible growth on agar plate was recorded as MBC [26]. 


\subsection{Quantitative Analysis of Pyocyanin Production in P. aeruginosa PAO1}

Inhibition of pyocyanin production was assessed according to previously described procedures [27]. P. aeruginosa PAO1 was grown (18 h in LB broth, $37^{\circ} \mathrm{C}, 175 \mathrm{rpm}$ agitation), and cells were washed twice in fresh LB medium. In 18 culture tubes, appropriately diluted PAO1 cell suspension $(250 \mu \mathrm{L})$ was added to the LB medium $(4.7 \mathrm{~mL}$, starting OD600nm ranged between 0.02 and $0.03)$ and supplemented with plant extract $(50 \mu \mathrm{L}, 10 \mathrm{mg} / \mathrm{mL}$ in DMSO) or DMSO. At periodic time intervals $(3 \mathrm{~h})$, tubes $(n=3)$ were sampled to assess bacterial growth ( $\mathrm{ufc} / \mathrm{mL})$ and pyocyanin content.

From each tube, $100 \mu \mathrm{L}$ of bacterial culture were removed and diluted in LB broth to be plated onto LB agar and incubated $\left(24 \mathrm{~h}, 37^{\circ} \mathrm{C}\right)$ for colony counting, while $200 \mu \mathrm{L}$ of bacterial culture was used to determine optical density at $600 \mathrm{~nm}$. Remaining bacterial culture was centrifuged (7000 rpm, $\left.10 \mathrm{~min}, 24^{\circ} \mathrm{C}\right)$ to obtain culture supernatant. Pyocyanin was extracted from the supernatant $(4 \mathrm{~mL})$ with chloroform $(2 \mathrm{~mL})$ and re-extracted from chloroform with $0.2 \mathrm{M} \mathrm{HCl}(1 \mathrm{~mL})$. Optical density reading at $380 \mathrm{~nm}$ allows pyocyanin determination.

\subsection{Quantitative Analysis of Violacein Production in C. violaceum CV026}

Inhibition of violacein production in C. violaceum CV026 was tested according to [27]. Violacein production was induced in C. violaceum CV026 by adding exogenous $N$-hexanoyl-L-homoserine lactone (HHL; Sigma-Aldrich Chemie GmbH, Darmstadt, Germany).

An appropriately diluted overnight culture of $C$. violaceum $\mathrm{CV} 026(200 \mu \mathrm{L})$ was incubated $\left(30^{\circ} \mathrm{C}\right.$, $48 \mathrm{~h}, 175 \mathrm{rpm}$ agitation) in 18 culture tubes containing LB broth (4.7 mL) supplemented with HHL $(50 \mu \mathrm{L}, 10 \mathrm{mM}$ in DMSO) and plant extract $(50 \mu \mathrm{L}, 10 \mathrm{mg} / \mathrm{mL}$ in DMSO) or DMSO. At periodic time intervals $(6 \mathrm{~h})$, tubes $(n=3)$ were sampled to assess bacterial growth ( $\mathrm{ufc} / \mathrm{mL}$ and OD600 $\mathrm{nm})$ and pyocyanin content, while violacein was quantified after $48 \mathrm{~h}$ growth.

From each tube, bacterial culture $(1 \mathrm{~mL})$ was centrifuged $(7000 \mathrm{rpm}, 10 \mathrm{~min})$ and DMSO $(1 \mathrm{~mL})$ was added to the pellet. The solution was vortexed to dissolve violacein, and cell debris was discarded by centrifugation (7000 rpm, $10 \mathrm{~min}$ ). Violacein content in supernatant was measured by the absorbance at $585 \mathrm{~nm}$.

\section{8. $\beta$-Galactosidase Assay}

$\beta$-Galactosidase measurements were performed as previously described [27]. After growth in liquid LB-MOPS-Carbenicillin ( $37{ }^{\circ} \mathrm{C}$ with $175 \mathrm{rpm}$ agitation) for $18 \mathrm{~h}$, PAO1 reporter strains harboring plasmids (Table S1) were washed twice in fresh LB medium and resuspended in fresh liquid LB-MOPS-Carbenicillin. PAO1 reporter strains inoculums $(50 \mu \mathrm{L})$ were incubated $\left(37{ }^{\circ} \mathrm{C}\right.$ with $175 \mathrm{rpm}$ agitation) for 8 or $18 \mathrm{~h}$ in $1 \mathrm{~mL}$ of LB-MOPS-Carbenicillin (initial OD600 $\mathrm{nm}$ of culture comprised between 0.020 and 0.025$)$ supplemented with $10 \mu \mathrm{L}$ of plant extracts ( $100 \mu \mathrm{g} / \mathrm{mL}$ final concentration) or $10 \mu \mathrm{L}$ of DMSO. After incubation, bacterial density was assessed by spectrophotometry (OD600 nm), and the sample used for cell growth assessment was used to perform the $\beta$-galactosidase assay with O-nitrophenyl- $\beta$-D-galactopyranoside as described elsewhere [28].

\subsection{Statistical Analysis}

All experiments were performed in triplicate (independent assays), and data were expressed as mean \pm SD. Data analysis was performed via analysis of variance (one-way ANOVA or two-way ANOVA) followed by a Tukey or Bonferonni test, using GraphPad Prism software (version 5.00 for window, GraphPad Software, San Diego, CA, USA) $p$ value $\leq 0.05$ was considered significant. 


\section{Results}

\subsection{Antioxidant Activity, Total Polyphenol, and Flavovoid Content}

Total polyphenol and total flavonoid were quantified from methanol extract of $A$. leiocarpus stem bark together with its antioxidant capacity through radicals DPPH scavenging activity and ferric reducing power, and each antioxidant assay involved a different antioxidant mechanism. The amount of total polyphenol was particularly high (82.62 $\pm 3.16 \mathrm{mg}$ GAE/100 mg) in addition to a low content of total flavonoid $(15.14 \pm 0.39 \mathrm{mg} \mathrm{QE} / 100 \mathrm{mg})$. As shown, an interesting antioxidant potential was found. A. leiocarpus exhibits the same DPPH radical scavenging activity $(1.82 \pm 0.07 \mu \mathrm{g} / \mathrm{mL})$ as quercetin $(1.40 \pm 0.15 \mu \mathrm{g} / \mathrm{mL})$, while its ferric-reducing power $(4.29 \pm 0.19 \mu \mathrm{M} \mathrm{AAE} / \mathrm{g})$ was only two-fold lower than that of our antioxidant reference $(7.66 \pm 0.39 \mu \mathrm{M} \mathrm{AAE} / \mathrm{g})$.

\subsection{Inhibition of Pyocianin Production}

The MIC (1.25 mg/mL) and MBC (>5.00 mg/mL) values evaluated allow for the selection of a sub-inhibitory concentration for the bioassay on P. aeruginosa PAO1. Methanol extract from $A$. leiocarpus stem bark $(100 \mu \mathrm{g} / \mathrm{mL})$ was incubated for $18 \mathrm{~h}$ in P. aeruginosa PAO1 culture to access its capacity to interfere with the production of pyocyanin, a QS-dependent extracellular virulence factor of the bacteria. As shown, methanol extract from A. leiocarpus (100 $\mu \mathrm{g} / \mathrm{mL}$ final concentration) significantly impact $(p<0.05)$ in a kinetic way the production of pyocyanin (Figure 1a) without any effect on bacterial kinetic growth (Figure 1b). Hence, the reduction of pyocyanin production recorded within $18 \mathrm{~h}$ was not the consequence of any bactericidal or bacteriostatic effect but probably the effect of some interference with the QS mechanism of P. aeruginosa PAO1, controlling the production of pyocyanin.

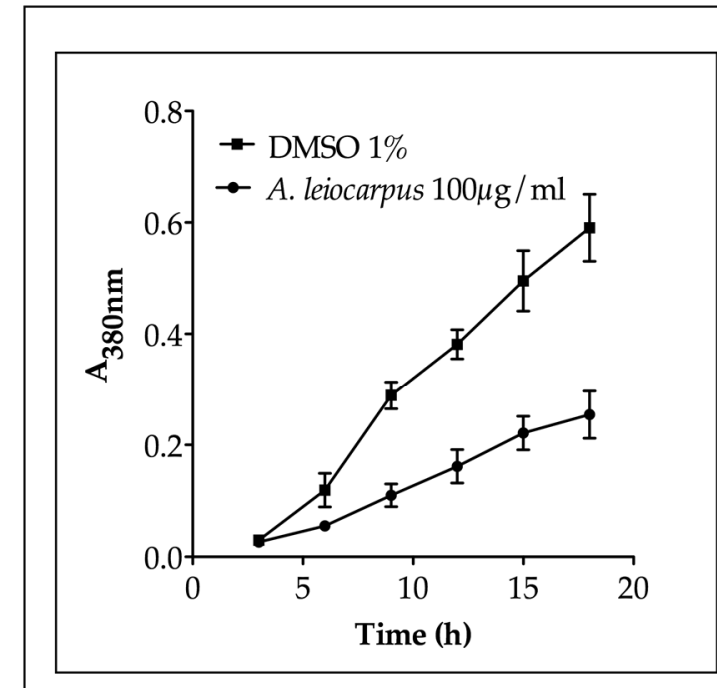

a) Kinetic of pyocyanin production

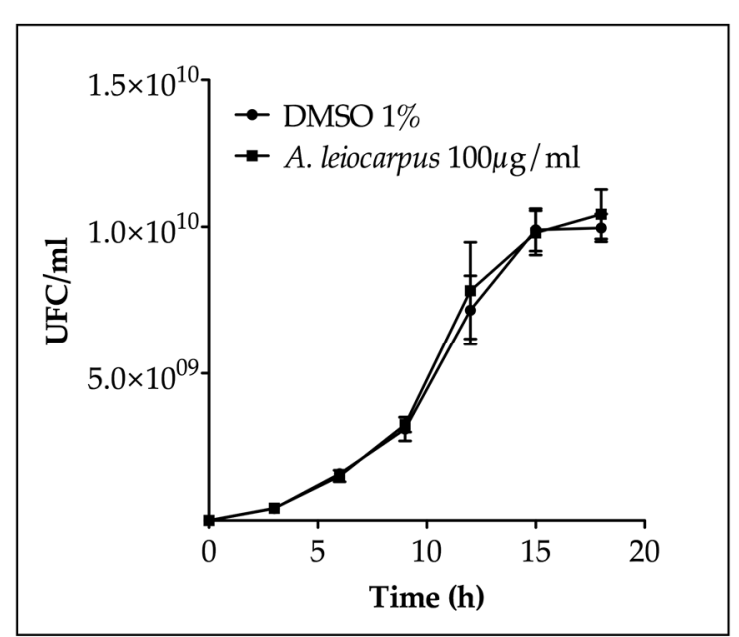

b) Kinetic growth of $P$. aeruginosa PAO1

Figure 1. Methanol extract from A. leiocarpus reduce pyocyanin production in P. aeruginosa PAO1. (a) A. leiocarpus extract $(100 \mu \mathrm{g} / \mathrm{mL})$ significantly reduced $(p>0.05)$ pyocyanin production within $18 \mathrm{~h}$ compared to DMSO used as control; (b) A. leiocarpus extract $(100 \mu \mathrm{g} / \mathrm{mL})$ did not exhibit a significant effect on P. aeruginosa PAO1 kinetic growth within $18 \mathrm{~h}$. Dimethyl sulfoxide (DMSO) was used as negative control. P. aeruginosa PAO1 was grown $\left(37^{\circ} \mathrm{C}, 175 \mathrm{rpm}\right.$ agitation) in the LB broth. Mean values $\pm \mathrm{SD}$ of triplicate independent experiments are shown.

\subsection{Anti-Quorum Sensing Activity}

To assess the ability of the methanol extract from A leiocarpus stem bark to interfere with the quorum sensing mechanism, the reporter strain C. violaceum CV026, deficient in the homoserine-lactone 
synthase gene cvil, was used. This strain is unable to produce quorum sensing auto inducers (homoserine-lactones) by itself, nor therefore the QS-related violacein, without an external supply of homoserine-lactone. The MIC $(0.62 \mathrm{mg} / \mathrm{mL})$ and MBC $(2.50 \mathrm{mg} / \mathrm{mL})$ values evaluated allow for the selection of a sub-inhibitory concentration for the bioassay on C. violaceum CV026. Methanol extract from $A$. leiocarpus ( $100 \mu \mathrm{g} / \mathrm{mL}$ final concentration) reduced violacein production by up to $50 \%$ (Figure 2a) without any effect on bacterial kinetic growth (Figure $2 b$ ). Therefore, the reduction of violacein production observed was not due to any bactericidal or bacteriostatic effect, but to a quenching of the QS system of the bacteria. When extract was added to C. violaceum CV026 growth medium without a HHL supply, violacein was not produced, indicating that $A$. leiocarpus extract do not contain mimic HHL compound (data not shown).

In order to evidence any interference with the expression of quorum sensing (QS) genes of $P$. aeruginosa PAO1, we focused on the transcriptional level after $18 \mathrm{~h}$ of incubation. Therefore, the expression of the HHL synthetases genes (lasI and $r h l I$ ), the QS regulator genes (lasR and $r h l R$ ), and the virulence factor QS-controlled genes (lasB and $r h l A$ ) were evaluated. As shown (Figure 3), methanol extract of $A$. leiocarpus stem bark did not significantly affect $(p<0.05)$ the transcription level of the quorum sensing lasI, lasR, and rhlI genes, while expression of rhlR was significantly $(p<0.05)$ downstreamed.

To determine whether the drop in $\beta$-galactosidase activity recorded was not due to an effect on the transcription/translation mechanisms, nor to an inhibition of the enzyme ( $\beta$-galactosidase), a $P$. aeruginosa PAO1 strain harboring the aceA-lacZ fusion (aceA gene encoding for isocitrate lyase) was tested. As shown, A. leiocarpus extract had no effect on the transcription of the ace $A$ gene, demonstrating that it affects the expression of QS-related genes without interfering with the entire transcription machinery of P. aeruginosa PAO1. Hence, A. leiocarpus methanol extract clearly exhibited anti-QS activity on P. aeruginosa PAO1.

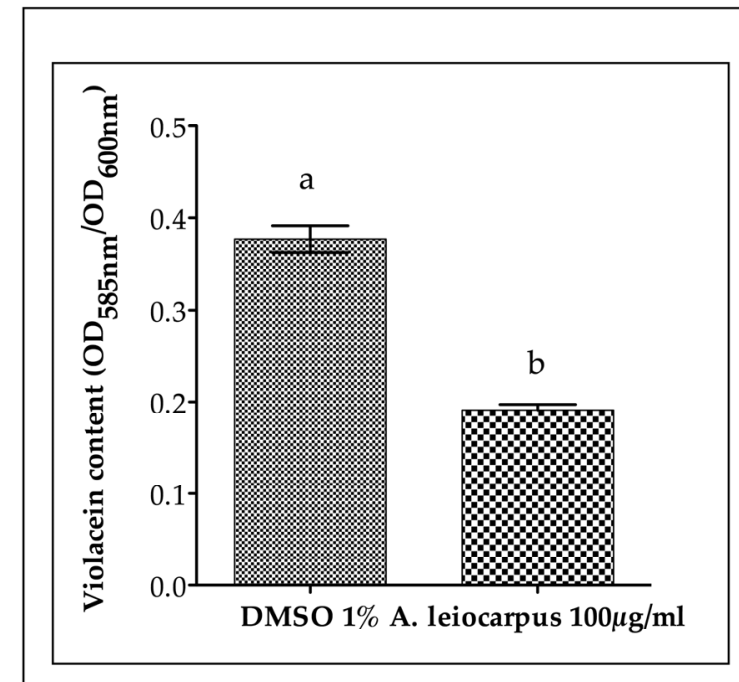

a) Violacein produced by C. bacterium CV026

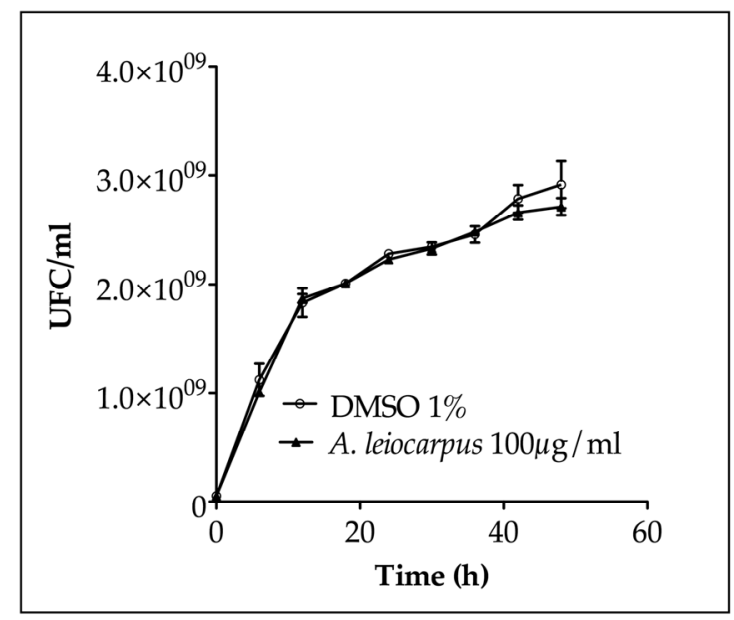

b) Kinetic growth of C. bacterium CV026

Figure 2. Anti-quorum sensing (QS) activity of methanol extract from A. leiocarpus. (a) A. leiocarpus extract $(100 \mu \mathrm{g} / \mathrm{mL})$ significantly reduces $(p>0.05)$ violacein production by $C$. violaceum $\mathrm{CV} 026$ within $48 \mathrm{~h}$ (b) A. leiocarpus extract $(100 \mu \mathrm{g} / \mathrm{mL})$ did not exhibit a significant effect of on C. violaceum CV026 kinetic growth within $48 \mathrm{~h}$. Dimethyl sulfoxide (DMSO) was used as a negative control. C. violaceum CV026 was grown $\left(30^{\circ} \mathrm{C}, 175 \mathrm{rpm}\right.$ agitation) in LB broth supplemented with HHL (10 $\mu \mathrm{M}$ in DMSO). Mean values of triplicate independent experiments and SD are shown. Data with different letters in superscript are significantly different $(p>0.05)$. 


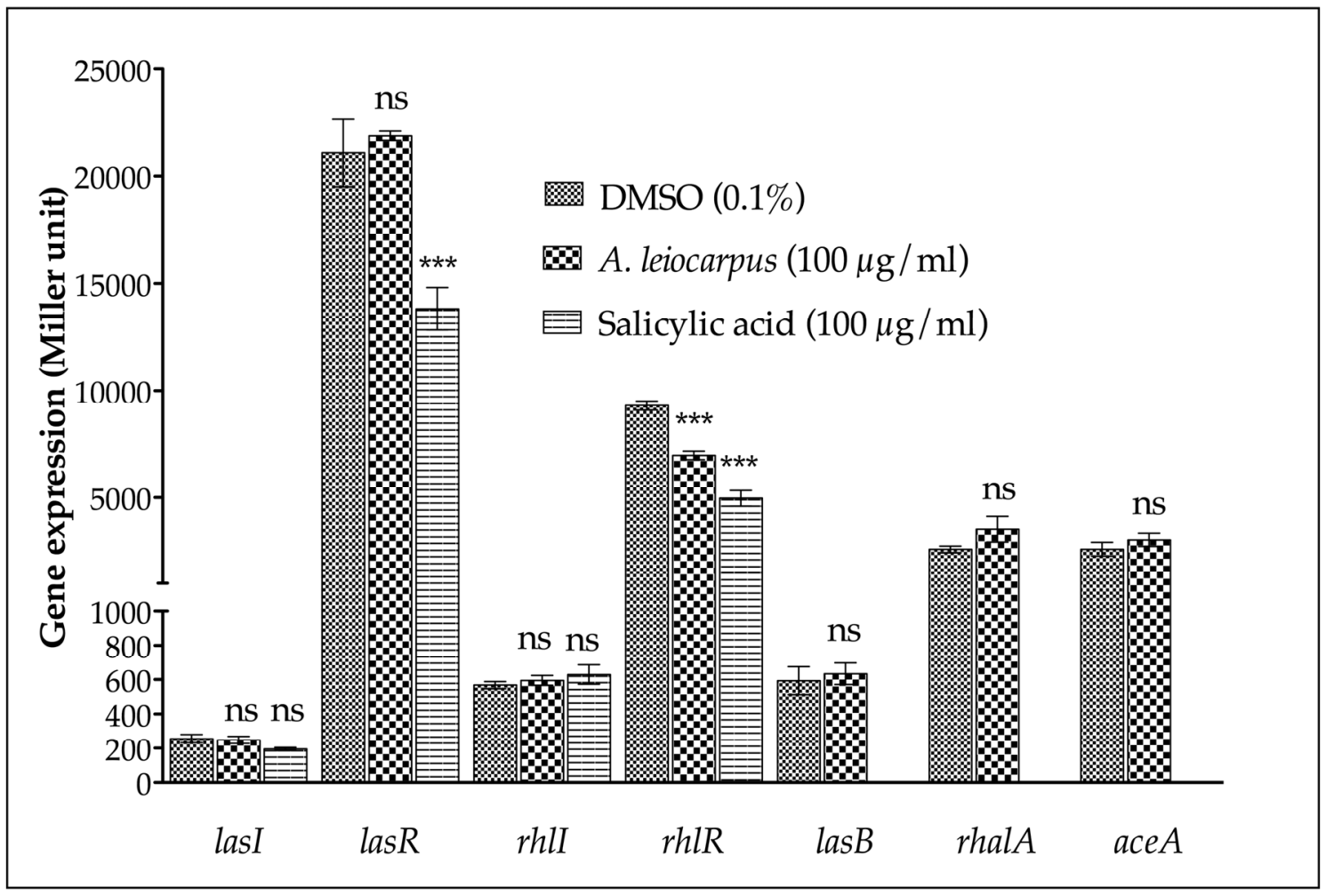

Figure 3. Effect of A. leiocarpus extract on the transcription level of lasRI and rhlRI QS genes. Data are expressed as mean \pm SD of 3 independent essays. Dimethyl sulfoxide (DMSO) was used as negative control. Salicylic acid was used as positive control. *** Significantly different compared with DMSO treatment $(p<0.05)$. ns: not significantly different compared to DMSO treatment. Gene expression was measured as the $\beta$-galactosidase activity of the lac $Z$ gene fusions and expressed in Miller units. Expression of the aceA gene is used as a quorum-sensing independent control. P. aeruginosa PAO1 strains were grown.

\section{Discussion}

Our in vitro investigations show that methanol extract from A. leiocarpus stem bark exhibits promising antioxidant capacity along with anti-QS activity with a subsequent reduction of pyocyanin production. Since $p h z$, the biosynthesis genes of pyocyanin, is under the control of las and $r h l$ QS systems $[29,30]$, the observed decrease in pyocyanin production is related to the downstreaming of the QS regulator gene rhlR.

P. aeruginosa PAO1 QS systems las and $r h l$ seems to be important for a successful infection in burn wounds, as the virulence of PAO1 mutants defective in either lasI, lasR, or rhlI is reduced [31]. Consistent with this, the inability of QS-deficient strains to induce a successful infection was proposed to be linked with a decreased production of virulence factors such as pyocyanin among other virulence factors, and the most significant virulence reduction was detected with the mutant defective in both lasI and rhlI [31]. Hence, the anti-QS demonstrated might explain the traditional usage of A. leiocarpus stem bark to treat infected burn wounds.

Within the Combretaceae family, to which belongs A. leiocarpus, anti-QS medicinal plants have been previously reported. Bucida buceras, Combretum albiflorum, and Conocarpus erectus quench the QS mechanism of P. aeruginosa PAO1 with a subsequent inhibition of the bacteria virulence factors [27,32]. Polyphenols and flavonoids are also known for their anti-QS potentiality. The flavonoids catechin, isolated from Combretum albiflorum and naringenin have been reported to inhibit QS-regulated virulence factors expression in P. aeruginosa and thought to possibly interfere with the perception of the native AHL by LasR and RhlR [27,33]. Epigallocatechin gallate, tannic acid, and ellagic acid also 
demonstrated their anti-QS potential against Pseudomonas putida [34]. Vescalagin and castalagin, two ellagitannins isolated from Conocarpus erectus, decrease AHL production, QS gene expression and elastases production [35]. The anti-QS activity and related reduction of pyocyanin production observed within our study might be due to castalagin, since it has been previously isolated from the stem bark of A. leiocarpus [36]. Furthermore, 3,3', $4^{\prime}$-tri-O-methylflavellagic acid, 3,3'-di-O-methylellagic acid, and 3,4,3'-tri-O-methylflavellagic acid- $4^{\prime}-\beta$-D-glucoside, three ellagic acid derivatives isolated from A. leiocarpus stem bark [37], might contribute to the anti-QS bioactivity we demonstrated.

Among several virulence factors produced by P. aeruginosa, pyocyanin is known to be involved in cell host degradation and the production of ROS [38,39]. Pyocyanin alters the redox cycle involved in cellular respiration and increases the oxidative stress on host cells [1]. The mechanism by which pyocyanin causes cell cycle arrest is related to its redox (oxidation-reduction) properties, and its ability to reduce molecular oxygen into reactive oxygen species induces low-level, yet persistent, oxidative stress [40,41]. Thus, pyocyanin is able to delay cicatrization and might also lead to chronic inflammation in wound and burn injuries infected by P. aeruginosa. Polyphenols and flavonoids responsible for the antioxidant activity of $A$. leiocarpus could therefore contribute to the reduction of the oxidative stress caused by pyocyanin and thus reduce inflammatory intensity independently of pyocyanin reduction, a benefit for wound healing.

Taken together, anti-QS and antioxidant activities of A. leiocarpus could contribute to an explanation of its wound-healing benefit. The antioxidant activities could represent a preventive action to minimize ROS due to inflammation but also counterbalance the high level production of ROS when burn injuries are infected by opportunistic pathogens. Additionally, the anti-QS activity also preserves a minimal ROS level as it reduces virulence factor production such as pyocyanin, and more importantly reduce the abilities of pathogens to degrade host tissue and to resist host immune responses that can maintain inflammation and delay the healing process.

\section{Conclusions}

Our study demonstrated the antioxidant and anti-QS activities of the methanol extract from A. leiocarpus stem bark. Based on bibliographic reports, catalagin and ellagic acid derivatives might be responsible for the anti-QS property demonstrated. These results contribute to the establishment of the traditional use of $A$. leiocarpus stem bark in the management of infected burn wounds on a rational basis. By reducing the production of pyocyanin and related oxidative stress within infected tissues in a QS manner, A. leiocarpus stem bark benefits to the healing process of septic injuries.

In future investigations, we will focus on the interference of the anti-QS molecules from A. leiocarpus either with the mechanisms of perception or production of homoserine lactones (lasI/lasR, $\mathrm{rhlI} / \mathrm{rhlR}$ QS systems) or with the quinolone signal (the third QS system) within P. aeruginosa.

Supplementary Materials: The following are available online at www.mdpi.com/2305-6320/3/4/26/s1. Table S1: List of plasmids used in this study.

Acknowledgments: The authors are grateful to Prof Mondher EL JAZIRI from the Laboratoire de Biotechnologie Vegetale, Univerté Libre de Bruxelles, Belgium, for providing the bacterial strains used in this study. This research was funded by The World Academy of Science (TWAS) under the research grant 12-044/RG/BIO/AF/AC-G-UNESCO FR: 3240271326.

Author Contributions: M.K. conceived and designed the experiments; V.O. performed the experiments; M.K. and V.O. analyzed the data and wrote the paper; M.K. provided reagents and material through a research grant awarded to him.

Conflicts of Interest: The authors declare no conflict of interest. The founding sponsor had no role in the design of the study; in the collection, analyses, or interpretation of data; in the writing of the manuscript, or in the decision to publish the results.

\section{References}

1. Liu, G.Y.; Nizet, V. Color me bad: Microbial pigments as virulence factors. Trends Microbiol. 2009, 17, 406-413. [CrossRef] [PubMed] 
2. Rumbaugh, K.P.; Griswold, J.A.; Hamood, A.N. The role of quorum sensing in the in vivo virulence of Pseudomonas aeruginosa. Microbes Infect. 2000, 2, 1721-1731. [CrossRef]

3. Richard, P.; le Floch, R.; Chamoux, C.; Pannier, M.; Espaze, E.; Richet, H. Pseudomonas aeruginosa outbreak in a burn unit: Role of antimicrobials in the emergence of multiply resistant strains. J. Infect. Dis. 1994, 170, 377-383. [CrossRef] [PubMed]

4. Greenberg, E.P. Acyl-homosérine lactone quorum sensing in bacteria. J. Microbiol. 2000, 38, 117-121.

5. Jimenez, P.N.; Koch, G.; Thompson, J.A.; Xavier, K.B.; Cool, R.H.; Quax, W.J. The multiple signaling systems regulating virulence in Pseudomonas aeruginosa. Microbiol. Mol. Biol. Rev. 2012, 76, 46-65. [CrossRef] [PubMed]

6. Parsek, M.R.; Greenberg, E.P. Sociomicrobiology: The connections between quorum sensing and biofilms. Trends Microbiol. 2005, 13, 27-33. [CrossRef] [PubMed]

7. Pesci, E.C.; Pearson, J.P.; Seed, P.C.; Iglewski, B.H. Regulation of las and rhl quorum sensing in Pseudomonas aeruginosa. J. Bacteriol. 1997, 179, 3127-3132. [PubMed]

8. Venturi, V. Regulation of quorum sensing in Pseudomonas. FEMS Microbiol. Rev. 2006, 30, 274-291. [CrossRef] [PubMed]

9. Diggle, S.P.; Winzer, K.; Chhabra, S.R.; Worrall, K.E.; Cámara, M.; Williams, P. The Pseudomonas aeruginosa quinolone signal molecule overcomes the cell density-dependency of the quorum sensing hierarchy, regulates $r h l$-dependent genes at the onset of stationary phase and can be produced in the absence of LasR. Mol. Microbiol. 2003, 50, 29-43. [CrossRef] [PubMed]

10. McKnight, S.L.; Iglewski, B.H.; Pesci, E.C. The Pseudomonas quinolone signal regulates rhl quorum sensing in Pseudomonas aeruginosa. J. Bacteriol. 2000, 182, 2702-2708. [CrossRef] [PubMed]

11. Pesci, E.C.; Milbank, J.B.; Pearson, J.P.; McKnight, S.; Kende, A.S.; Greenberg, E.P.; Iglewski, B.H. Quinolone signaling in the cell-to-cell communication system of Pseudomonas aeruginosa. Proc. Natl. Acad. Sci. USA 1999, 96, 11229-11234. [CrossRef] [PubMed]

12. Wade, D.S.; Calfee, M.W.; Rocha, E.R.; Ling, E.A.; Engstrom, E.; Coleman, J.P.; Pesci, E.C. Regulation of Pseudomonas quinolone signal synthesis in Pseudomonas aeruginosa. J. Bacteriol. 2005, 187, 4372-4380. [CrossRef] [PubMed]

13. Gibran, N.S.; Heimbach, D.M. Current status of burn wound pathophysiology. Clin. Plast. Surg. 2000, 27, 11-22. [PubMed]

14. Farina, J.A., Jr.; Rosique, M.J.; Rosique, R.G. Curbing inflammation in burn patients. Int. J. Inflamm. 2013. [CrossRef] [PubMed]

15. Ward, P.A.; Lentsch, A.B. The acute inflammatory response and its regulation. Arch. Surg. 1999, 134, 666-669. [CrossRef] [PubMed]

16. Rahman, I.; MacNee, W. Regulation of redox glutathione levels and gene transcription in lung inflammation: Therapeutic approaches. Free Radic. Biol. Med. 2000, 28, 1405-1420. [CrossRef]

17. Wang, J.; Blanchard, T.G.; Ernst, P.B. Host Inflammatory Response to Infection in Helicobacter pylori: Physiology and Genetics; Mobley, H.L.T., Mendz, G.L., Hazell, S.L., Eds.; ASM Press: Washington, DC, USA, 2001.

18. Epps, L.C.; Walker, P.D. Fluoroquinolone consumption and emerging resistance. US Pharm. 2006, 10, 47-54.

19. English, B.K.; Gaur, A.H. The use and abuse of antibiotics and the development of antibiotic resistance. Adv. Exp. Med. Biol. 2010, 659, 73-82. [PubMed]

20. Bjarnsholt, T.; Givskov, M. The role of quorum sensing in the pathogenicity of the cunning aggressor Pseudomonas aeruginosa. Anal. Bioanal. Chem. 2007, 387, 409-414. [CrossRef] [PubMed]

21. Hentzer, M.; Givskov, M. Pharmacological inhibition of quorum sensing for the treatment of chronic bacterial infections. J. Clin. Investig. 2003, 112, 1300-1307. [CrossRef] [PubMed]

22. Nacoulma, O.G. Plantes Médicinales et Pratiques Médicinales Traditionnelles au Burkina; Université de Ouagadougou: Ouagadougou, Burkina Faso, 1996. (In French)

23. Agyare, C.; Asase, A.; Lechtenberg, M.; Niehues, M.; Deters, A.; Hensel, A. An ethnopharmacological survey and in vitro confirmation of ethnopharmacological use of medicinal plants used for wound healing in Bosomtwi-Atwima-Kwanwoma area, Ghana. J. Ethnopharmacol. 2009, 125, 393-403. [CrossRef] [PubMed]

24. Lamien-Meda, A.; Lamien, C.E.; Compaoré, M.M.Y.; Meda, N.T.R.; Kiendrebeogo, M.; Zeba, B.; Millogo, J.F.; Nacoulma, O.G. Polyphenol content and antioxidant activity of fourteen wild edible fruits from Burkina Faso. Molecules 2008, 13, 581-594. [CrossRef] [PubMed] 
25. Eloff, J.N. A sensitive and quick microplate method to determine the minimal inhibitory concentration of plant extracts for bacteria. Planta Med. 1998, 64, 711-713. [CrossRef] [PubMed]

26. Escalona-Arranz, J.C.; Péres-Roses, R.; Urdaneta-Laffita, I.; Camacho-Pozo, M.I.; Rodríguez-Amado, J.; Licea-Jiménez, I. Antimicrobial activity of extracts from Tamarindus indica L. leaves. Pharmacogn. Mag. 2010, 6, 242-247. [CrossRef] [PubMed]

27. Vandeputte, O.M.; Kiendrebeogo, M.; Rajaonson, S.; Diallo, B.; Mol, A.; El Jaziri, M.; Baucher, M. Identification of catechin as one of the flavonoids from Combretum albiflorum bark extract that reduces the production of quorum-sensing-controlled virulence factors in Pseudomonas aeruginosa PAO1. Appl. Environ. Microbiol. 2010, 76, 243-253. [CrossRef] [PubMed]

28. Zhang, X.; Bremer, H. Control of the Escherichia coli rrnB P1 promoter strength by ppGpp. J. Biol. Chem. 1995, 270, 11181-11189. [CrossRef] [PubMed]

29. Pearson, J.P.; Pesci, E.C.; Iglewski, B.H. Roles of Pseudomonas aeruginosa las and rhl quorum-sensing systems in control of elastase and rhamnolipid biosynthesis genes. J. Bacteriol. 1997, 179, 5756-5767. [PubMed]

30. Brint, J.; Ohman, D.E. Synthesis of multiple exoproducts in Pseudomonas aeruginosa is under the control of RhlR-RhlI, another set of regulators in strain PAO1 with homology to the autoinducer-responsive LuxR-LuxI family. J. Bacteriol. 1995, 177, 7155-7163. [PubMed]

31. Rumbaugh, K.P.; Griswold, J.A.; Iglewski, B.H.; Hamood, A.N. Contribution of quorum sensing to the virulence of Pseudomonas aeruginosa in burn wound infections. Infect. Immun. 1999, 67, 5854-5862. [PubMed]

32. Adonizio, A.; Kong, K.; Mathee, K. Inhibition of quorum sensing-controlled virulence factor production in Pseudomonas aeruginosa by south Florida plant extracts. Antimicrob. Agents Chemother. 2008, 52, 198-203. [CrossRef] [PubMed]

33. Vandeputte, O.M.; Kiendrebeogo, M.; Rasamiravaka, T.; Stévigny, C.; Duez, P.; Rajaonson, S.; Diallo, B.; Mol, A.; Baucher, M.; El Jaziri, M. The flavanone naringenin reduces the production of quorum sensing-controlled virulence factors in Pseudomonas aeruginosa PAO1. Microbiology 2011, 157, 2120-2132. [CrossRef] [PubMed]

34. Huber, B.; Eberl, L.; Feucht, W.; Polster, J. Influence of polyphenols on bacterial biofilm formation and quorum-sensing. Z. Naturforsch. C 2003, 58, 879-884. [CrossRef] [PubMed]

35. Adonizio, A.L. Anti-Quorum Sensing Agents from South Florida Medicinal Plants and Their Attenuation of Pseudomonas aeruginosa Pathogenicity; Florida International University: Miami, FL, USA, 2008.

36. Shuaibu, M.N.; Pandey, K.; Wuyep, P.A.; Yanagi, T.; Hirayama, K.; Ichinose, A.; Tanaka, T.; Kouno, I. Castalagin from Anogeissus leiocarpus mediates the killing of Leishmania in vitro. Parasitol. Res. 2008, 103, 1333-1338. [CrossRef] [PubMed]

37. Chaabi, M.; Benayache, S.; Benayache, F.; N’Gom, S.; Koné, M.; Anton, R.; Weniger, B.; Lobstein, A. Triterpenes and polyphenols from Anogeissus leiocarpus (Combretaceae). Biochem. Syst. Ecol. 2007, 36, 59-62. [CrossRef]

38. Gloyne, L.S.; Grant, G.D.; Perkins, A.V.; Powell, K.L.; McDermott, C.M.; Johnson, P.V.; Anderson, G.J.; Kiefel, M.; Anoopkumar-Dukie, S. Pyocyanin-induced toxicity in A549 respiratory cells is causally linked to oxidative stress. Toxicol. In Vitro 2011, 25, 1353-1358. [CrossRef] [PubMed]

39. Tamura, Y.; Suzuki, S.; Kijima, M.; Takahashi, T.; Nakamura, M. Effect of proteolytic enzyme on experimental infection of mice with Pseudomonas aeruginosa. J. Vet. Med. Sci. 1992, 54, 597-599. [CrossRef] [PubMed]

40. Muller, M. Premature cellular senescence induced by pyocyanin, a redox-active Pseudomonas aeruginosa toxin. Free Radic. Biol. Med. 2006, 41, 1670-1677. [CrossRef] [PubMed]

41. Muller, M.; Li, Z.; Maitz, P.K. Pseudomonas pyocyanin inhibits wound repair by inducing premature cellular senescence: Role for p38 mitogen-activated protein kinase. Burns 2009, 35, 500-508. [CrossRef] [PubMed]

(C) 2016 by the authors; licensee MDPI, Basel, Switzerland. This article is an open access article distributed under the terms and conditions of the Creative Commons Attribution (CC-BY) license (http://creativecommons.org/licenses/by/4.0/). 